\title{
Egzosomy jako nowy element komunikacji w pęcherzyku jajnikowym ssaków
}

\begin{abstract}
STRESZCZENIE
$\mathbf{P}$ ęcherzyk jajnikowy wraz z wypełniającym go płynem pęcherzykowym tworzy optymalne środowisko do wzrostu oraz dojrzewania oocytu. Płyn pęcherzykowy zawiera wiele aktywnych biologicznie cząsteczek, które regulują funkcje oocytu i komórek somatycznych pęcherzyka jajnikowego. Ostatnie doniesienia naukowe dowodzą obecności egzosomów w płynie pęcherzykowym ludzi i zwierząt. Te nanometrowe, kuliste struktury, otoczone dwuwarstwą lipidową niosą aktywny ładunek biologiczny w postaci białek, lipidów, cukrów oraz materiału genetycznego. Dzięki zdolności do biernej migracji w płynach ustrojowych, egzosomy przemieszczają się na znaczne odległości w organizmie i modulują funkcje komórek docelowych. Znaczenie egzosomów w pęcherzyku jajnikowym nie zostało wciąż do końca poznane. Dotychczasowe badania sugerują ich rolę komunikacyjną oraz wpływ na procesy fizjologiczne i patologiczne $w$ jajniku. Badania nad egzosomami płynu pęcherzykowego dają możliwość dokładniejszego poznania procesów, w które są one zaangażowane w pęcherzyku jajnikowym. Ponadto potencjalne kliniczne zastosowanie egzosomów, np. w leczeniu i diagnostyce chorób żeńskiego układu rozrodczego, skłania naukowców do dalszych badań.
\end{abstract}

\section{WPROWADZENIE}

Płyn pęcherzykowy stanowi niezbędne mikrośrodowisko dla rozwijającego się oocytu. Zawiera on bogaty zestaw składników, które pełnią funkcję odżywczą oraz zapewniają komunikację pomiędzy komórkami pęcherzyka jajnikowego i kompleksem wzgórka jajonośnego z oocytem (COC, ang. cumulus-oophorus complex) [1]. W ostatnich latach w płynie pęcherzykowym zidentyfikowano kuliste nanostruktury otoczone dwuwarstwową błoną lipidową, nazywane egzosomami. Dzięki obecności bioaktywnych składników w swoim wnętrzu (białka, lipidy, materiał genetyczny) oraz zdolności do krążenia w płynach ustrojowych, pełnią one głównie funkcję komunikacyjną i są odpowiedzialne za przekazywanie informacji między różnymi typami komórek. Mogą one także wbudowywać się w zespoły komórek modulując przy tym ich funkcje, zarówno w procesach fizjologicznych i patologicznych [2]. Ogromny potencjał egzosomów w aspekcie biologicznym, diagnostycznym i terapeutycznym składnia naukowców do nieustannych badań nad tymi strukturami. Jest to dość utrudnione ze względu na ich mały rozmiar oraz brak optymalnej metody izolacji [3]. Na przełomie ostatnich kilku lat egzosomy zidentyfikowano w płynie peccherzykowym ludzi i innych ssaków [4]. Potwierdzenie ich obecności w pęcherzykach jajnikowych oraz analiza przenoszonego przez nie ładunku molekularnego może mieć znaczenie dla głębszego poznania mechanizmów regulujących funkcje pęcherzyka jajnikowego.

\section{BUDOWA PECCHERZYKA JAJNIKOWEGO}

Pęcherzyki jajnikowe, powstające i dojrzewające w jajniku w procesie folikulogenezy, stanowią rezerwuar rozrodczy samicy. Ich głównym zadaniem jest produkcja komórek jajowych zdolnych do zapłodnienia. Rozwój pęcherzyków rozpoczyna się od stadium pęcherzyka pierwotnego, który następnie przekształca się w pęcherzyk pierwszo-, drugo- i trzeciorzędowy, kończąc dojrzewanie na etapie pęcherzyka przedowulacyjnego (pęcherzyka Graafa). Od momentu wejścia w stadium trzeciorzędowe, pęcherzyki jajnikowe nazywamy antralnymi, ze względu na obecność w nich jamki (antrum) wypełnionej płynem pęcherzykowym. Płyn ten stanowi niezbędne środowisko odżywcze dla znajdującego się wewnątrz oocytu [5]. Najbardziej zewnętrzną warstwę pęcherzyka antralnego stanowi osłonka zewnętrzna, zbudowana z komórek mięśni gładkich, fibroblastów, włókien kolagenowych i naczyń krwionośnych. Kolejną warstwę tworzy osłonka wewnętrzna, która oprócz komórek steroidogennych zawiera także komórki zrębu łącznotkankowego i naczynia krwionośne. Dalej usytuowana jest błona podstawna, będąca barierą między krwią a wnętrzem pęcherzyka. Gra-

\section{Katarzyna Popiołek ${ }^{1}$,}

\section{Małgorzata Grzesiak ${ }^{2 \varpi}$}

${ }^{1}$ Katedra Fizjologii i Endokrynologii Zwierząt, Wydział Hodowli i Biologii Zwierząt, Uniwersytet Rolniczy w Krakowie, Kraków

${ }^{2}$ Zakład Endokrynologii, Instytut Zoologii i Badań Biomedycznych, Wydział Biologii, Uniwersytet Jagielloński w Krakowie, Kraków

https://doi.org/10.18388/pb.2019_276

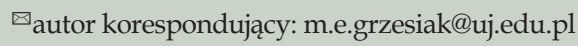

Słowa kluczowe: egzosomy, pęcherzyki zewnątrzkomórkowe, płyn pęcherzykowy, pęcherzyk jajnikowy

Wykaz skrótów: ALG-2 (ang. apoptosis-linked gene-2 product) - białko związane $\mathrm{z}$ apoptozą, eEF1 (ang. encaryotic elongation factor-1) - eukariotyczny czynnik-1 elongacji translacji, eIF4 (ang. eucaryotic initiation factor- $\underline{4}$ ) - eukariotyczny czynnik-4 inicjacji translacji, ESCRT (ang. endosomal sorting complex required for transport) - endosomalny kompleks sortujący, MFGE8 (ang. milk fat globule EGF/factor VIII) - laktadheryna, PI3K (ang. phosphoinositide ㅈkinase) - kinaza fosfatydyloinozytolu, SNARE (ang. soluble $\underline{N}$-ethylmaleiamide-sensitive factor attachment protein receptor) - rodzina białek SNARE, TPxII (ang. thioredoxin peroxidase II) - peroksydaza II tioredoksyny, TSAP6 (ang. protein tumor suppressor-activated pathway $\underline{6}$ ) - białko supresorowe nowotworu, TSG101 (ang. tumor susceptibility gene $\underline{101}$ product) - produkt genu TSG101 

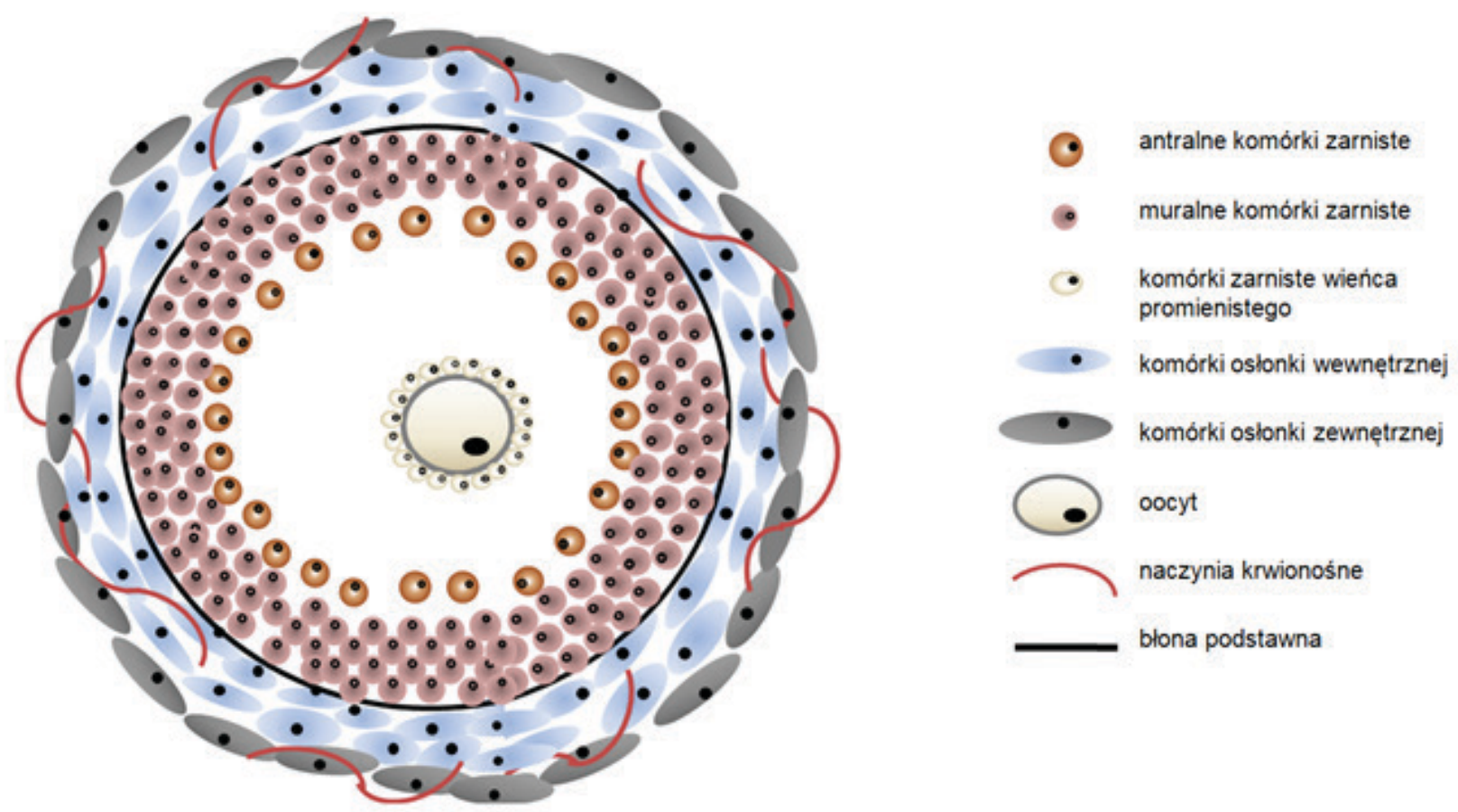

Rycina 1. Budowa antralnego pęcherzyka jajnikowego ssaków. Opis w tekście.

niczy ona $\mathrm{z}$ awaskularną warstwą komórek ziarnistych, wśród których wyróżnia się komórki muralne, wsparte na błonie podstawnej oraz komórki antralne, otaczające jamkę pęcherzyka. Pierwsze z nich mają kolumnowaty kształt i wykazują większą aktywność steroidogenną. Drugie są bardziej kuliste i luźniej ułożone. Jako osobną populację komórek ziarnistych, wyodrębnia się komórki wieńca promienistego, które otaczają oocyt i tworzą wzgórek jajonośny [5] (Ryc. 1).

W pęcherzyku jajnikowym dochodzi do ciągłej, dwukierunkowej wymiany molekuł między oocytem a komórkami somatycznymi. Wzajemna interakcja jest uwarunkowana lokalną produkcją hormonów, czynników wzrostu oraz innych cząsteczek aktywnych biologicznie, które działają na drodze auto- lub parakrynowej [4]. Wśród czynników uwalnianych przez oocyt najważniejszymi są białko morfogenetyczne kości 15 (BMP15, ang. bone morphogenetic protein 15) oraz czynnik wzrostu i różnicowania 9 (GDF9, ang. growth differentiation factor 9), które wpływają na proliferację i różnicowanie komórek ziarnistych. Natomiast w przeciwnym kierunku wydzielane są m.in. Kit ligand i nabłonkowe czynniki wzrostu odpowiadające za dojrzewanie oocytu [4]. Bardzo ważnym elementem komunikacji pomiędzy komórkami ziarnistymi oraz pomiędzy oocytem i komórkami ziarnistymi są połączenia szczelinowe (ang. gap junctions). Zapewniają one przenoszenie sygnału elektrycznego, przepływ nieorganicznych jonów, wtórnych przekaźników i innych cząsteczek rozpuszczalnych $\mathrm{w}$ wodzie o masie poniżej 1,0 kDa. Zbudowane są z białek zwanych koneksynami (Cx, ang. connexin), które łączą się w kompleksy i tworzą kanały przezkomórkowe. Pomiędzy komórkami ziarnistymi występują głównie Cx43 i Cx45, natomiast w komunikacji pomiędzy oocytem, a komórkami wieńca promienistego pośredniczą Cx37 i Cx43 [6]. Za nowy element komunikacji wewnątrz pęcherzyka jajnikowego uważa się obecnie egzosomy, które są uwalniane do płynu pęcherzykowego i transportują molekuły regulujące ekspresję genów w oocycie [4].

\section{PEYN PĘCHERZYKOWY - FORMOWANIE, SKEAD I FUNKCJA}

Etap powstawania płynu pęcherzykowego rozpoczyna się już w późnych pęcherzykach drugorzędowych. Dochodzi wówczas do rozluźniania i reorganizacji dotychczas zwartej warstwy komórek ziarnistych oraz powstawania szczelin, które następnie łączą się ze sobą tworząc jamkę [7]. Powstała jamka wypełniona jest płynem pęcherzykowym będącym efektem dyfuzji substancji z naczyń krwionośnych znajdujących się w osłonce pęcherzyka, a także zawierającym składniki produkowane przez komórki ziarniste, komórki osłonki wewnętrznej oraz oocyt [8,9]. Istnieje hipoteza zakładająca, że akumulacja płynu pęcherzykowego zależy od utworzenia gradientu osmotycznego, który powoduje przemieszczanie się substancji z osocza do wnętrza pęcherzyka. Powstawanie gradientu jest możliwe dzięki substancjom produkowanym przez komórki ziarniste - hialuronianowi i siarczanowi chondroityny (wersikan). Transfer ten może przebiegać w dwojaki sposób - międzykomórkowo oraz przezkomórkowo. $\mathrm{W}$ pierwszym przypadku przesącz z osocza przedostaje się pomiędzy komórkami śródbłonka naczyń krwionośnych oraz pomiędzy komórkami ziarnistymi do wnętrza pęcherzyka. Drugi mechanizm angażuje białka budujące kanały wodne, czyli akwaporyny (AQP, ang. aquaporin) lub procesy transcytozy (transport substancji przez cytoplazmę komórki z jednego jej bieguna na drugi) [10]. Badania przeprowadzone na ludzkich, mysich oraz szczurzych pęcherzykach jajnikowych dowiodły obecności akwaporyn różnych klas (AQP 1-4, 7-9) w komórkach ziarnistych. Ponadto Starowicz i in. [11] wykazali obecność 
AQP5 w błonie oocytów przedantralnych i antralnych pęcherzyków jajnikowych szczurów. Jej ekspresja w przedantralnych pęcherzykach jajnikowych oraz zanik w pęcherzykach owulacyjnych może wskazywać, że przyczynia się ona do magazynowania wody $\mathrm{w}$ antrum.

Płyn pęcherzykowy stanowi niezwykle ważne mikrośrodowisko dla rozwijającego się oocytu, zapewniające dostęp do niezbędnych substancji odżywczych. Jednymi z najważniejszych składników płynu są hormony m.in.: hormon folikulotropowy (FSH, ang. follicle-stimulating hormone), luteinizujący ( $\mathrm{LH}$, ang. luteinizing hormone) oraz gonadotropina kosmówkowa (hCG, ang. human chorionic gonadotropin). Wpływają one na wydzielanie różnych substancji przez komórki ziarniste (np. kwasu hialuronowego), które oddziałują na oocyt. Oprócz gonadotropin w płynie pęcherzykowym znajduje się hormon wzrostu, progesteron, estradiol, prolaktyna, gonadoliberyna, a także androgeny i kortykosteroidy [12]. Płyn pęcherzykowy to również zestaw wielu czynników wzrostu m.in.: nabłonkowego czynnika wzrostu (EGF, ang. epidermal growth factor), EGF-podobnego czynnika wzrostu, transformującego czynnika wzrostu a oraz $\beta$ (TGF-a,- $\beta$, ang. transforming growth factor), insulinopodobnego czynnika wzrostu (IGF, ang. insulin-like growth factor), inhibiny oraz aktywiny [12,13]. Ponadto w skład płynu pęcherzykowego wchodzą czynniki apoptotyczne tj. Fas-ligand, którego kompleks z rozpuszczalnym czynnikiem Fas (sFas-FasL) może zapobiegać atrezji oocytów [14]. Płyn pęcherzykowy zawiera również białka w postaci cytokin, enzymów, antykoagulantów, a także aminokwasowych metabolitów. Warto wspomnieć o żelatynazach posiadających aktywność enzymatyczną, które są zaangażowane w przebudowę tkanki podczas atrezji pęcherzyków. Ponadto ważną funkcję pełnią reaktywne formy tlenu obecne w płynie pęcherzykowym, np. tlenek azotu, który może działać indukująco lub hamująco na apoptozę komórek pęcherzyka janikowego [14]. Płyn pęcherzykowy bogaty jest również we frakcję polisacharydów - hialuronian i mioinzoytol oraz w lipidowe metabolity wspomagające różnicowanie się oocytu [15].

Skład płynu pęcherzykowego jest dosyć różnorodny i zależy od etapu rozwoju pęcherzyka. Dla przykładu, we wzrastającym pęcherzyku antralnym zwiększa się poziom estrogenów, natomiast maleje stężenie heparanosiarczanu oraz siarczanu chondroityny [5]. Ponadto wiele składników płynu pęcherzykowego jest wykorzystywanych jako wskaźniki dojrzałości oocytów oraz ich gotowości do owulacji i zapłodnienia [14]. Równie interesującym elementem zidentyfikowanym w płynie pęcherzykowym zarówno ludzi jak i zwierząt są obłonione, kuliste nanostruktury przenoszące aktywny materiał biologiczny, czyli egzosomy. Mimo tego, że do niedawna uważane były za komórkowe odpady (ang. cell debris), obecnie są szeroko opisywane w literaturze. Potencjalne znaczenie egzosomów w funkcjonowaniu pęcherzyka jajnikowego sprawia, że stanowią one interesujący obiekt do badań naukowych [16].

\section{EGZOSOMY - KLASYFIKACJA, BIOGENEZA I CHARAKTERYSTYKA}

Pęcherzyki zewnątrzkomórkowe (EVs, ang. extracellular vesicles) to grupa struktur biologicznych uwalnianych do macierzy zewnątrzkomórkowej z powierzchni błon większości komórek ssaków. Dzięki zdolności do przenoszenia zestawu funkcjonalnych cząsteczek na duże odległości oraz do integracji z komórkami docelowymi, mogą uczestniczyć zarówno w procesach fizjologicznych, jak i patologicznych w organizmie. Wśród EVs wyróżniamy trzy główne typy: najmniejsze egzosomy, większe ektosomy (mikrocząstki, mikropęcherzyki) oraz największe ciałka apoptotyczne [17]. Podział ten opiera się głównie na kryterium wielkości, jed-

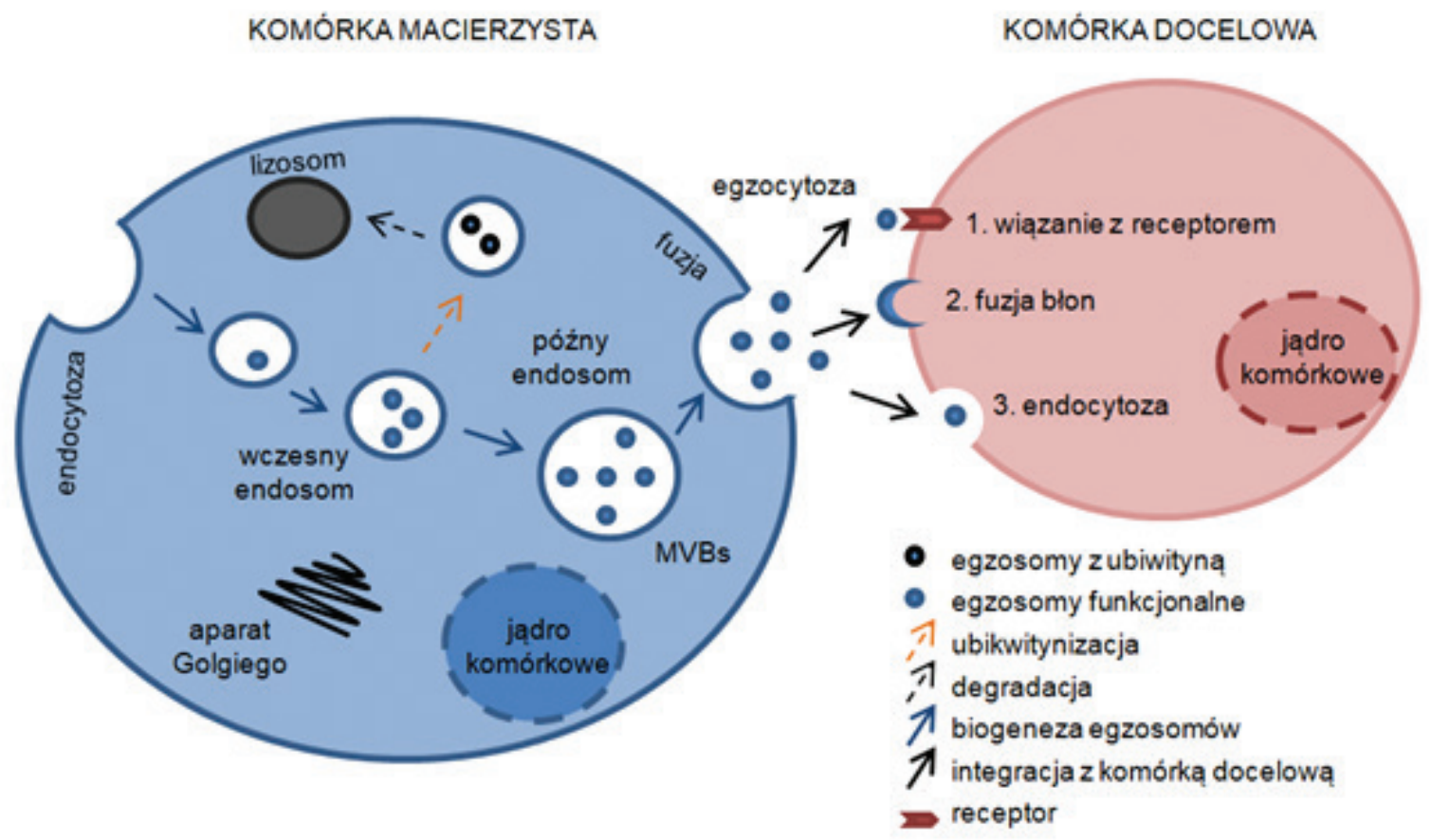

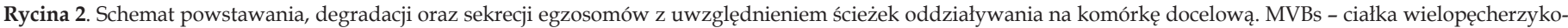
we. Opis w tekście. 
nak można je również klasyfikować ze względu na pochodzenie, sposób powstawania, skład biologiczny wewnątrz i na ich powierzchni oraz sposób ich izolacji [3]. Grupę najbardziej homogenną wśród EVs stanowią egzosomy, których średnica mieści się $\mathrm{w}$ granicach od 30 do nawet 150 nm $[18,19]$. Sa to kuliste struktury zaopatrzone w zestaw aktywnych biomolekuł (ang. cargo) otoczonych dwuwarstwową błoną lipidową, na powierzchni której znajdują się specyficzne markery [20]. Ich historia sięga lat 80-tych XX wieku, kiedy to egzosomy zostały zidentyfikowane jako małe pęcherzyki wydzielane podczas różnicowania się retikulocytów [21]. Jednakże Zeringer i in. [18] podają, że termin „egzosom” został wprowadzony po raz pierwszy już w 1981 roku przez Trams'a i in. [22] podczas badań nad wydzielniczą aktywnością linii komórkowych. Egzosomy mogą powstawać zarówno w warunkach in vivo, jak i in vitro u organizmów eukariotycznych oraz prokariotycznych [23]. Występują one w wielu płynach ustrojowych m.in.: krwi, nasieniu, moczu, ślinie, mleku, płynie otrzewnowym, owodniowym, mózgowo-rdzeniowym, żółci, płynie oskrzelowo-pęcherzykowym, a także w płynie pęcherzykowym $[18,24]$. Powstają w sposób konstytutywny w ciałkach wielopęcherzykowych (MVBs, ang. multivesicular bodies) zwanych endosomami późnymi. Z powierzchni błony komórkowej uwalniane są w procesie egzocytozy [20].

Sposób powstawania i uwalniania egzosomów z powierzchni komórki macierzystej różni się od mechanizmów tworzenia innych EVs. Można go podzielić na trzy główne etapy - pierwszy, polegający na powstawaniu MVBs na drodze endosomalnej, drugi na transporcie MVBs w kierunku błony plazmatycznej i ostatni, opierający się na uwolnieniu egzosomów na skutek fuzji MVBs z błoną komórkową (Ryc. 2) [25]. Na początku procesu biogenezy pęcherzyków dochodzi do internalizacji błony komórkowej w procesie endocytozy i tworzenia wczesnych endosomów. Następnie struktury te "pączkują", w związku z czym po pewnym czasie tworzą się endosomy późne (MVBs) zawierające liczne pęcherzyki. Następnie dochodzi do migracji MVBs w kierunku błony komórkowej, w co zaangażowany jest sortujący kompleks białkowy ESCRT (ang. endosomal sorting complex required for transport), który odpowiada także za organizację egzosomów wewnątrz MVBs. Ostatnie doniesienia naukowe sugerują istnienie alternatywnego mechanizmu formowania się egzosomów, który jest niezależny od ESCRT i angażuje błonowe lipidy oraz tetraspaniny $[4,26]$. Może zdarzyć się również tak, że pęcherzyki znajdujące się w MVBs zostaną poddane ubikwitynizacji i kierowane będą do degradacji w lizosomach (Ryc. 2).

Powstawanie pęcherzyków kontrolowane jest również przez białka z rodziny Rab: Rab5, Rab7, Rab11, Rab 27a/b, Rab35, które wraz z transbłonowym kompleksem SNARE (ang. soluble N-ethylmaleiamide-sensitive factor attachment protein receptor) towarzyszą MVBs, aż do momentu ich fuzji z błoną komórkową i uwolnienia funkcjonalnych egzosomów do macierzy zewnątrzkomórkowej $[23,26]$. Najnowsze badania wskazują, że w tworzeniu egzosomów bierze udział także białko przeciwnowotworowe p53 oraz jego efektor TSAP6, które wpływają stymulująco na ich produkcję. Ponadto inne badania sugerują, że syndekan, wchodząc w interakcję z białkiem ALIX poprzez motyw aminokwasowy
Leu-Tyr-Pro-X(n)-Leu, wpływa na endosomalne powstawanie egzosomów w MVBs [27]. Egzosomy powstające według przedstawionego powyżej mechanizmu mogą być uwalniane $\mathrm{z}$ różnych komórek $\mathrm{w}$ organizmie m.in.: płytek krwi, komórek odpornościowych, w tym limfocytów T, komórek nerwowych, w tym oligodendrocytów, czy komórek Schwanna, komórek nabłonków większości układów, w tym z komórek nabłonkowych jelit, endometrium, łożyska i błon śluzowych, komórek nowotworowych, a także komórek pęcherzyka jajnikowego $[16,18]$.

Ładunek biologiczny przenoszony przez EVs na ogół stanowi odzwierciedlenie składu komórek rodzicielskich. Jednak w przypadku egzosomów jest nieco inaczej, głównie ze względu na inny niż u pozostałych pęcherzyków zewnątrzkomórkowych mechanizm powstawania [23]. Niemniej jednak wszystkie EVs zbudowane są z dwuwarstwowej błony lipidowej o średniej grubości około 5 nm, w obrębie której znajdują się białka, lipidy oraz cukry, a także z ładunku molekularnego, który otacza ta błona [28]. W obrębie lipidów powierzchniowych charakterystycznym składnikiem błony egzosomalnej są tratwy lipidowe (ang. lipid rafts) w postaci sfingolipidów (m.in. ceramidu, który odróżnia te pęcherzyki od lizosomów), a także cholesterolu oraz fosfolipidów z długimi nasyconymi łańcuchami kwasów łłuszczowych [19]. Podczas tworzenia się egzosomów na drodze endocytarnej dochodzi do reorganizacji składników błony lipidowej, w związku z czym struktura ta różni się od powierzchni błony komórki macierzystej. Główna różnica polega na wbudowywaniu fosfatydyloseryny po zewnętrznej stronie błony egzosomów [29]. Ponadto zauważalna jest większa zawartość cholesterolu w pęcherzykach egzosomalnych w odróżnieniu od komórki, z której one pochodziły [30]. Dzięki tym substancjom błona egzosomów jest bardziej sztywna i wytrzymała w stosunku do komórki macierzystej [31]. Egzosomy posiadają charakterystyczne markery powierzchniowe, m.in. tetraspaniny: CD9, CD63, CD81, białka uczestniczace $\mathrm{w}$ transporcie i fuzji błonowej: GTPazy, aneksyny, flotyliny, białka głównego układu zgodności tkankowej MHC I oraz II, białko wiążące lipidy (MFGE8), integryny, peptydazy (CD13, CD26), galektynę 3, białka GPI-zakotwiczone (CD55, CD59) oraz inne białka transbłonowe. Natomiast we wnętrzu egzosomów znajdziemy białka szoku cieplnego (Hsc70, Hsp90, Hsp60, Hsp70), białka zaangażowane w biogenezę MVBs (Alix, TSG101, klatryna), białka z rodziny Rab, enzymy związane z procesem apoptozy (ALG-2, TPxII), białka cytoszkieletu (m.in. aktyna, tubulina, fibronektyna), białka sygnałowe (m.in. EGFR, PI3K) oraz enzymy (m.in. dehydrogenaza gliceroaldehydofosforanowa, kinaza fosfoglicerynianowa, ATP-azy, enolazy), a także czynniki translacyjne (m.in. eIF4, eEF1) [21,26]. Po zewnętrznej stronie egzosomów usytuowane są także łańcuchy cukrowe, tj. mannoza, polilaktozamina, kwas sjalowy oraz N-glikany [32].

Na ładunek egzosomów składa się również ważny element z punktu widzenia funkcjonowania komórek, czyli materiał genetyczny. W pęcherzykach egzosomalnych obecne są zarówno cząsteczki kwasu deoksyrybonukleinowego (DNA), jak i kwasu rybonukleinowego (RNA), w tym głównie mRNA oraz mikroRNA (miRNA) [19]. Transkrypt przeniesiony do komórki docelowej może w niej ulegać 
Tabela 1. Przykłady funkcji egzosomów wizolowanych z płynu pęcherzykowego ssaków.

\begin{tabular}{|c|c|c|c|}
\hline Model doświadczalny & Metoda izolacji & Funkcja egzosomów & Piśmiennictwo \\
\hline Klacz & ExoQuick & $\begin{array}{l}\text { Transport białek i miRNA, regulacja funkcji } \\
\text { komórek ziarnistych i jakości oocytu }\end{array}$ & [24] \\
\hline Bydło & $\begin{array}{l}\text { ExoQuick } \\
\text { Ultrawirowanie różnicujące }\end{array}$ & $\begin{array}{l}\text { Transport miRNA, regulacja dojrzewania } \\
\text { pęcherzyka jajnikowego i wzrostu oocytu }\end{array}$ & [38] \\
\hline Klacz & $\begin{array}{l}\text { ExoQuick } \\
\text { Ultrawirowanie różnicujące }\end{array}$ & $\begin{array}{l}\text { Regulacja dojrzewania pęcherzyka jajnikowego poprzez wpływ } \\
\text { na szlak sygnalizacyjny TGF } \beta \text { / BMP w komórkach ziarnistych }\end{array}$ & [41] \\
\hline Człowiek & Ultrawirowanie różnicujące & Transport miRNA i wpływ na płodność & [42] \\
\hline Człowiek & Ultrawirowanie różnicujące & $\begin{array}{l}\text { Transport miRNA, regulacja wzrostu pęcherzyka } \\
\text { jajnikowego i dojrzewania ooctu }\end{array}$ & [43] \\
\hline Klacz & ExoQuick & Transport miRNA i wpływ na rozwój pęcherzyka antralnego & [37] \\
\hline Klacz & ExoQuick & $\begin{array}{l}\text { Transport miRNA i wpływ na dojrzewanie } \\
\text { pęcherzyków jajnikowych poprzez regulację ekspresji } \\
\text { czynników należących do nadrodziny TGF } \beta\end{array}$ & [44] \\
\hline Bydło & Ultrawirowanie różnicujące & $\begin{array}{l}\text { Transport miRNA, rola zależna od stadium } \\
\text { rozwoju pęcherzyka jajnikowego }\end{array}$ & [45] \\
\hline Świnia & Total Exosome Isolation Reagent & Rola w ekspansji wzgórka jajonośnego & [39] \\
\hline Świnia & Total Exosome Isolation Reagent & Funkcja zależna od stadium rozwoju pęcherzyka jajnikowego & [46] \\
\hline Człowiek & Total Exosome Isolation Reagent & $\begin{array}{l}\text { Transport circRNA, rola w patogenezie } \\
\text { zespołu policystycznych jajników }\end{array}$ & [47] \\
\hline
\end{tabular}

ekspresji, z kolei miRNA odgrywa ważną rolę $\mathrm{w}$ regulacji ekspresji wielu genów. W składzie egzosomów w mniejszej ilości znajdziemy także niekodujące RNA (m.in. saRNA, piRNA, snoRNA), transportowe RNA (tRNA) oraz rybosomalne RNA (rRNA) [18]. Dosyć duża powtarzalność składu białkowego większości egzosomów wskazuje, że sposób ich powstawania nie opiera się na przypadkowym uwalnianiu z powierzchni błony komórek, lecz jest ściśle ukierunkowany [23]. Dodatkowo fakt, że powierzchnia egzosomów nie jest całkowitym odzwierciedleniem błony komórki macierzystej również potwierdza to założenie. Dzięki temu wiemy już, że struktury te nie są jedynie błonowymi „resztkami", lecz odgrywają kluczową rolę w wielu istotnych procesach biologicznych.

Egzosomom przypisuje się dużą rolę w procesach zachodzących na poziomie komórkowym. Jedną z podstawowych funkcji egzosomów jest komunikacja międzykomórkowa, zarówno na niewielkie, jak i duże odległości przy udziale różnorodnych płynów ustrojowych. Przenoszenie sygnału biologicznego przez egzosomy stanowi nową formę transportu w układach wielokomórkowych, co jest niezwykle istotne dla rozwoju organizmów wyższych. Ponadto pęcherzyki te biorą udział w procesach tj. koagulacja, prezentowanie antygenów, „zarządzanie” resztkami komórkowymi, ale także angiogeneza, proliferacja, starzenie się komórek, apoptoza, różnicowanie, przenoszenie sygnałów immunologicznych [19]. Wpływ egzosomów na wyżej wymienione procesy widoczny jest niemal we wszystkich tkankach organizmów żywych, co potwierdza ogromny potencjał funkcjonalny tych struktur. Co ciekawe, ostatnie doniesienia wskazują, że egzosomy pełnią również istotną funkcję w układzie rozrodczym. Mogą one oddziaływać na gamety żeńskie i męskie, przez co wpływają na proces zapłodnie- nia, implantację zarodka, a nawet na przebieg ciąży modulując odpowiedź immunologiczną matki [16,33]. Jednak oprócz oddziaływania egzosomów na procesy fizjologiczne, zauważono również dużą ich aktywność w procesach patologicznych, m.in. w chorobach neurodegeneracyjnych, nowotworach czy AIDS [34-36].

\section{FUNKCJA EGZOSOMÓW W PĘCHERZYKU JAJNIKOWYM}

W literaturze naukowej pojawiają się coraz częściej doniesienia na temat obecności egzosomów w dotychczas nieprzebadanych pod tym kątem płynach ustrojowych. Interesującym materiałem okazał się być także płyn pęcherzykowy, zarówno ludzi i zwierząt. Po raz pierwszy egzosomy zostały wyizolowane i scharakteryzowane przez da Silveira i in. [24] u klaczy w 2012 roku. Wykryto w nich materiał genetyczny w postaci miRNA, który dalej został opisany pod względem funkcji jakie może pełnić w komórkach pęcherzyka jajnikowego [37]. U bydła jako pierwsi egzosomy wyizolowali Sohel i in. [38], wykazując przy tym, podobnie jak u klaczy, że przenoszą one miRNA. Egzosomy w płynie pęcherzykowym świni zidentyfikowano w 2017 roku [39]. W tym samym roku Keningsberg i in. [40] opublikowali protokół izolacji egzosomów, w którym po raz pierwszy wprowadzili termin "folikulosom” (ang. folliculosome) dla określenia egzosomów pochodzących z płynu pęcherzykowego, co podkreśla specyficzne pochodzenie wyizolowanych struktur. Odkrycie egzosomów u zwierząt skłoniło naukowców także do badań nad ludzkimi pęcherzykami jajnikowymi $[42,43,47]$. W Tabeli 1 przedstawiono chronologicznie przykłady modeli doświadczalnych, u których izolowano egzosomy z płynu pęcherzykowego z uwzględnieniem pełnionych przez nie funkcji oraz metody izolacji. 
Kluczowym elementem w analizie egzosomów jest wybór odpowiedniej metody ich izolacji uwzględniającej niezbędne parametry tego procesu [3]. Najczęściej wybieraną metodą izolacji egzosomów z płynu pęcherzykowego są komercyjne zestawy do precypitacji EVs, charakteryzujące się krótką procedurą oraz nie wymagające użycia ultrawirówki. Są to zestawy ExoQuick ${ }^{\mathrm{TM}}$ (System Biosciences) oraz Total Exosome Isolation Reagent ${ }^{\mathrm{TM}}$ (ThermoFisher Scientific) [40]. Oprócz łatwej procedury izolacji, zestawy te mają także inne zalety m.in. zdolność do wytrącania egzosomów przy neutralnym $\mathrm{pH}$ oraz wysokich stężeniach jonów [48]. Ze względu na aspekt ekonomiczny, oprócz komercyjnych zestawów stosuje się również ultrawirowanie, wirowanie $\mathrm{w}$ gradiencie gęstości, metody chromatograficzne (np. chromatografia wykluczenia SEC, chromatografia powinowactwa) oraz metody immunologiczne (np. kulki magnetyczne opłaszczone przeciwciałami) [3,40]. Biorąc pod uwagę objętość płynu pęcherzykowego w pojedynczym pęcherzyku antralnym (u ludzi około $100 \mu \mathrm{l}$ ), istnieją pewne ograniczenia $\mathrm{w}$ procesie izolacji. W tej małej objętości płynu pęcherzykowego znajduje się wiele białek m.in. immunoglobuliny czy albuminy, które mogą maskować EVs w dalszych etapach analizy. Ponadto $\mathrm{w}$ przypadku metody wykorzystującej ultrawirowanie $\mathrm{w}$ wysokich prędkościach możliwa jest degradacja struktury EVs, co jest zjawiskiem niepożądanym [3]. Natomiast przy komercyjnych zestawach zdarza się, że zastosowane odczynniki chemiczne zakłócają dalsze analizy jakościowe lub ilościowe egzosomów. Mimo tego, zestawy oparte na precypitacji glikolem polietylenowym są wciąż najczęściej stosowaną metodą pozyskiwania egzosomów. Należy również pamiętać, że nie wszystkie metody odpowiednie do izolacji egzosomów z medium hodowlanego nadają się do ich izolacji z płynów ustrojowych. Zawierają one więcej składników białkowych i komórkowych zanieczyszczeń, które można wyeliminować z próbki wprowadzając dodatkowe etapy podczas izolacji, np. proces filtracji $[3,40]$.

Istnieje wiele hipotez dotyczących zaangażowania egzosomów zarówno w fizjologiczne, jak i patologiczne procesy zachodzące w jajniku, jednak większość z nich wciąż czeka na potwierdzenie. Wśród najczęściej opisywanych funkcji egzosomów wymienia się te związane $\mathrm{z}$ transportem miRNA. Ważnym aspektem jest również obecność innych funkcjonalnych komponentów m.in. niekodującego RNA (ncRNA), mitochondrialnego DNA (mtDNA) oraz białek [4]. Elementem białkowego składu egzosomów są cytokiny, które znane są ze zdolności do pełnienia funkcji regulującej proces proliferacji i różnicowania komórek w pęcherzyku jajnikowym, atrezji pęcherzyka oraz dojrzewania oocytu [49]. Innym przykładem białkowych komponentów egzosomalnych są białka z rodziny Wnt, zaangażowane w komórkowe szlaki sygnalizacyjne. Receptory dla tych białek ulegają ekspresji na określonych etapach rozwoju pęcherzyka jajnikowego oraz podczas luteinizacji $[4,50]$. Zbadanie mechanizmów funkcjonowania tych szlaków w kontekście działania egzosomów wydaje się być niezbędne do lepszego zrozumienia procesu folikulogenezy.

Egzosomy są również przedmiotem badań w kontekście ekspresji genów odpowiedzialnych za dojrzewanie oocytu.
U klaczy dowiedziono, że egzosomy wpływają na ekspresję genów TGFß i BMP15 [44]. Najnowsze doniesienia wskazują, że ich ekspresja zmienia się $\mathrm{w}$ różnych warunkach środowiska. Naukowcy badali wpływ szoku cieplnego u krów na dojrzewanie oocytów in vitro. Geny odpowiedzialne za jakość oocytu (m.in. BMP15, GDF9) wykazywały mniejszą ekspresje $\mathrm{w}$ warunkach temperaturowo neutralnych $\mathrm{w}$ stosunku do tych, które zostały narażone szok cieplny [51]. Ponadto inne badania wykazały, że egzosomy regulują dojrzewanie oocytu $\mathrm{w}$ zależności od poziomu ekspresji miRNA [38]. Następnie Hung i in. [52] wskazali, że folikulosom pęcherzyków antralnych u bydła wpływa na ekspansję komórek kompleksu COC. Ten sam zespół wykazał na modelu bydlęcym, że egzosomalne miRNA mogą modulować ekspresję genów zaangażowanych w ten proces, który jest kluczowy dla prawidłowej owulacji. Sugeruje to obecność nowego mechanizmu regulującego ekspansję COCs, który może wpływać na utrzymanie płodności przez samice [53].

Wiele badań naukowych poświęconych jest tematyce egzosomalnego miRNA i to właśnie jego działanie opisywane jest najczęściej w odniesieniu do egzosomów. Santonocito i in. [43] wykazali, że folikulosom ludzi zawiera różne rodzaje miRNA (np. miR-99a, miR-100, miR-132), które mogą regulować szlaki biologiczne krytyczne dla rozwoju i dojrzewania oocytu. Istnieje wiele hipotez, w których egzosomalne miRNA odgrywa kluczową rolę $\mathrm{w}$ folikulogenezie. Jednym z przykładów jest wpływ miRNA folikulosomu na aktywację szlaku PI3K w komórkach ziarnistych i oocycie, odpowiedzialnego za dojrzewanie pęcherzyków jajnikowych.

Obecność EVs wykazano w płynach pochodzących z żeńskiego (pęcherzyk jajnikowy, macica, jajowód) oraz męskiego (najądrze, prostata) układu rozrodczego [54-56]. Oprócz wyżej wymienionych fizjologicznych funkcji egzosomów, w literaturze opisano również ich znaczenie $\mathrm{w}$ stanach patologicznych organizmu. Campoy i in. [57] wyizolowali frakcję egzosomów pochodzącą z płynu macicznego kobiet $\mathrm{z}$ łagodnymi schorzeniami ginekologicznymi. Ponadto Sang i in. [58] izolowali pęcherzyki różnych klas z płynu pęcherzykowego kobiet z zespołem policystycznych jajników (PCOS, ang. polycystic ovarian syndrome). Najnowsze badania przeprowadzone na grupie pacjentek z PCOS dowiodły obecności $\mathrm{w}$ płynie pęcherzykowym zestawu kolistych RNA (circRNA, ang. circular RNA) pochodzenia egzosomalnego, z których większość zaangażowana była w procesy występujące $w$ patogenezie PCOS tj. infekcje bakteryjne, stres oksydacyjny czy autofagia. Badania te są podwaliną do dalszych analiz dotyczących roli tych cząsteczek w patogenezie PCOS [47]. Najnowsze prace odnoszą się także do roli egzosomów jako potencjalnych biomarkerów nowotworu jajnika. W EVs izolowanych z surowicy krwi kobiet z nowotworem jajnika obserwowano wysoką ekspresję miR21, miR-141, miR-200 i miR-214 [59]. U tych pacjentek analizowano także obecność egzosomów w moczu i wykazano w nich podwyższony poziom miR-30a-5p, który korelował ze stadium rozwoju nowotworu [60]. Dowiedziono, że EVs są również nośnikami białka CA125, markera nowotworu jajnika, a jego poziom jest wyższy w EVs niż w surowicy krwi we wczesnym stadium nowotworu. Sugeruje się, że drugim ważnym białkiem diagnostycznym transportowanym przez 
EVs może być klaudyna 4, gdyż jej ekspresja pozytywnie koreluje ze stadium rozwoju nowotworu [61]. Najnowsze prace wskazują, że oprócz miRNA i białek, także inne molekuły egzosomalne (np. fosfatydyloseryna) mogą być obiecującymi markerami wykorzystywanymi w diagnostyce nowotworu jajnika [61]. Wymaga to jednak dalszych badań.

Analizy folikulosomu prowadzone przez naukowców na przestrzeni ostatnich lat wskazują, że dziedzina ta dopiero zaczyna się rozwijać. Skupiają się one głównie na identyfikacji egzosomów w płynie pęcherzykowym oraz badaniu transportowanego przez nie materiału biologicznego. Szczegółowa analiza ładunku molekularnego jaki przenoszą dostarcza informacji o mechanizmie ich powstawania w pęcherzyku jajnikowym, a także pozwala przewidzieć potencjalny efekt ich działania. Ponadto egzosomy mogłyby zostać wykorzystane jako swoiste biomarkery do monitorowania jakości oocytów m.in. podczas zapłodnienia pozaustrojowego (IVF, ang. in vitro fertilization) u ludzi i zwierząt gospodarskich [4]. Oprócz tego warto zaznaczyć, że pęcherzyk jajnikowy jest bardzo dobrym modelem do badań egzosomów oraz mechanizmów zaangażowanych $\mathrm{w}$ ich transport. Stanowi on bowiem mały, zamknięty system, w którym łatwo wskazać komórki, z których EVs mogą się uwalniać i wbudowywać w sąsiednie tkanki [4]. W związku $\mathrm{z}$ tym konieczne jest dalsze badanie folikulosomu, co znajduje też swoje potwierdzenie we wzrastającej liczbie artykułów naukowych na ten temat.

\section{PIŚMIENNICTWO}

1. Kotarska K (2009) Ekspansja komórek ziarnistych wzgórka jajonośnego - proces niezbędny do prawidłowego przebiegu owulacji i zapłodnienia. Post Biol Kom 36: 171-187

2. Grzybowska A, Lorenc T, Olejarz W, Nowicka G (2019) Egzosomy jako nośniki informacji w komunikacji między komórkami nowotworowymi. Biuletyn WF WUM 2: 6-13

3. Popiołek K, Grzesiak M (2018) Metody izolacji pęcherzyków zewnątrzkomórkowych - zalety i wady. Post Biol Kom 45: 63-76

4. Di Pietro C (2016) Exosome-mediated communication in the ovarian follicle. J Assist Reprod Genet 33: 303-311

5. Szołtys M (1992) Struktura i funkcja pęcherzyków jajnikowych ssaków. Post Biol Kom 19: 221-238

6. Kidder GM, Vanderhyden BC (2010) Bidirectional communication between oocytes and follicle cells: ensuring oocyte developmental competence. Can J Physiol Pharmacol 88: 399-413

7. Fahiminiya S, Gérard N (2010) Follicular fluid in mammals. Gynecol Obstet Fertil 38: 402-404

8. Manarang-Pangan S, Menge AC (1971) Immunologic studies on human follicular fluid. Fertil Steril 22: 367-372

9. Kamiński T, Przała J (1994) Czynniki wzrostowe w jajniku. Post Biol Kom 21: 79-92

10. Rodgers RJ, Irving-Rodgers HF (2010) Formation of the ovarian follicular antrum and follicular fluid. Biol Reprod 82: 1021-1029

11. Starowicz A, Grzesiak M, Mobasheri A, Szołtys M (2014) Immunolocalization of aquaporin 5 during rat ovarian follicle development and expansion of the preovulatory cumulus oophorus. Acta Histochem 116: 457-465

12. Revelli A, Piane LD, Casano S, Molinari E, Massobrio M, Rinaudo P (2009) Follicular fluid content and oocyte quality: from single biochemical markers to metabolomics. Reprod Biol Endocrinol 7: 1-13

13. Rosairo D, Kuyznierewicz I, Findlay J, Drummond A (2008) Transforming growth factor-beta: its role in ovarian follicle development. Reproduction 136: 799-809
14. Malamitsi-Puchner A (2006) Novel follicular fluid factors influencing oocyte developmental potential in IVF: a review. Reprod BioMed 12: 500-506

15. Basuino L, Silveira CF Jr (2016) Human follicular fluid and effects on reproduction. JBRA Assist Reprod 20: 38-40

16. Nguyen HP, Simpson RJ, Salamonsen LA, Greening DW (2016) Extracellular vesicles in the intrauterine environment: challenges and potential functions. Biol Reprod 95: 1-12

17. Stępień E, Targosz-Korecka M (2013) Mikrocząstki w regulacji funkcji śródbłonka. Postepy Biochem 59: 395-404

18. Zeringer E, Barta T, Li M, Vlassov AV (2015) Strategies for isolation of exosomes. Cold Spring Harb Protoc 2015: 319-323

19. Li P, Kaslan M, Lee SH, Yao J, Gao Z (2017) Progress in exosome isolation techniques. Theranostics 7: 789-804

20.Surman M, Stępień E, Hoja-Łukowicz D, Przybyło M (2017) Deciphering the role of ectosomes in cancer development and progression: focus on the proteome. Clin Exp Metastasis 34: 273-289

21. Wesołowska A, Piwocka K (2017) Egzosomalne mikroRNA jako element komunikacji międzykomórkowej w nowotworach. Postepy Biochem 63: 110-118

22. Trams EG, Lauter CJ, Salem N Jr, Heine U (1981) Exfoliation of membrane ecto-enzymes in the form of micro-vesicles. Biochim Biophys Acta 645: 63-70

23. Wójtowicz A, Baj-Krzyworzeka M, Baran J (2014) Charakterystyka i znaczenie biologiczne mikropęcherzyków błonowych. Postep Hig Med Dosw 68: 1421-1432

24. Da Silveira JC, Veeramachaneni DN, Winger QA, Carnevale EM, Bouma GJ (2012) Cell-secreted vesicles in equine ovarian follicular fluid contain miRNAs and proteins: a possible new form of cell communication within the ovarian follicle. Biol Reprod 86: 1-10

25. Skotland T, Sandvig K, Llorente A (2017) Lipids in exosomes: Current knowledge and the way forward. Prog Lipid Res 66: 30-41

26. Xu R, Greening DW, Zhu H-J, Takahashi N, Simpson RJ (2016) Extracellular vesicle isolation and characterization: toward clinical application. Journal Clin Invest 126: 1152-1162

27. Zhang X, Yuan X, Shi H, Wu L, Qian H, Xu W (2015) Exosomes in cancer: small particle, big player. J Hematol Oncol 8: 83

28. Lobb RJ, Becker M, Wen SW, Wong CSF, Wiegmans AP, Leimgruber A, et al. (2015) Optimized exosome isolation protocol for cell culture supernatant and human plasma. J Extracell Vesicles 4: 27031

29. Fitzner D, Schnaars M, van Rossum D, Krishnamoorthy G, Dibaj P, Bakhti M, et al. (2011) Selective transfer of exosomes from oligodendrocytes to microglia by macropinocytosis. J Cell Sci 124: 447-458

30. Llorente A, Skotland T, Sylvänne T, Kauhanen D, Róg T, Orłowski A, et al. (2013) Molecular lipidomics of exosomes released by PC-3 prostate cancer cells. Biochim Biophys Acta 1831: 1302-1309

31. Zaborowski MP, Balaj L, Breakefield XO, Lai CP (2015) Extracellular vesicles: composition, biological relevance, and methods of study. Bioscience 65: 783-797

32. Laulagnier K, Motta C, Hamdi S, Roy S, Fauvelle F, Pageaux JF, et al. (2004) Mast cell- and dendritic cell-derived exosomes display a specific lipid composition and an unusual membrane organization. Biochem J 380: $161-171$

33. Tannetta D, Dragovic R, Alyahyaei Z, Southcombe J (2014) Extracellular vesicles and reproduction-promotion of successful pregnancy. Cell Mol Immunol 11: 548-563

34. Milane L, Singh A, Mattheolabakis G, Suresh M, Amiji MM (2015) Exosome mediated communication within the tumor microenvironment. J Control Release 219: 278-294

35. Howitt J, Hill AF (2016) Exosomes in the pathology of neurodegenerative diseases. J Biol Chem 291: 26589-26597

36. Konadu KA, Huang MB, Roth W, Armstrong W, Powell M, Villinger $\mathrm{F}$, et al. (2016) Isolation of exosomes from the plasma of HIV-1 positive individuals. J Vis Exp 107: e53495 
37. Da Silveira JC, de Andrade GM, Nogueira MF, Meirelles FV, Perecin F (2015) Involvement of miRNAs and cell-secreted vesicles in mammalian ovarian antral follicle development. Reprod Sci 22: 1474-1483

38. Sohel MMH, Hoelker M, Noferesti SS, Salilew-Wondim D, Tholen E, Looft C, et al. (2013) Exosomal and non-exosomal transport of extra-cellular micrornas in follicular fluid: implications for bovine oocyte developmental competence. PLoS ONE 8: e78505

39. Matsuno Y, Onuma A, Fujioka YA, Yasuhara K, Fujii W, Naito K, et al. (2017) Effects of exosome-like vesicles on cumulus expansion in pigs in vitro. J Reprod Dev 63: 51-58

40. Kenigsberg S, Wyse BA, Librach CL, da Silveira JC (2017) Protocol for exosome isolation from small volume of ovarian follicular fluid: evaluation of ultracentrifugation and commercial kits. Methods Mol Biol 1660: 321-341

41. Da Silveira JC, Carnevale EM, Winger QA, Bouma GJ (2014) Regulation of ACVR1 and ID2 by cell-secreted exosomes during follicle maturation in the mare. Reprod Biol Endocrinol 12: 44

42. Diez-Fraile A, Lammens T, Tilleman K, Witkowski W, Verhasselt B, De Sutter $P$, et al. (2014) Age-associated differential microRNA levels in human follicular fluid reveal pathways potentially determining fertility and success of in vitro fertilization. Hum Fertil (Camb.) 17: 90-98

43. Santonocito M, Vento M, Guglielmino MR, Battaglia R, Wahlgren J, Ragusa M, et al. (2014) Molecular characterization of exosomes and their microRNA cargo in human follicular fluid: bioinformatic analysis reveals that exosomal microRNAs control pathways involved in follicular maturation. Fertil Steril 102: 1751-1761

44. Da Silveira JC, Winger QA, Bouma GJ, Carnevale EM (2015) Effects of age on follicular fluid exosomal microRNAs and granulosa cell transforming growth factor- $\beta$ signalling during follicle development in the mare. Reprod Fertil Dev 27: 897-905

45. Navakanitworakul R, Hung WT, Gunewardena S, Davis JS, Chotigeat W, Christenson LK (2016) Characterization and small RNA content of extracellular vesicles in follicular fluid of developing bovine antral follicles. Sci Rep 6: 25486

46. Popiołek K, Grzesiak M (2019) Identification of exosomes in porcine ovarian follicular fluid - a new approach into cell-to-cell communication within the ovary. 5th International Conference of Cell Biology (Book of Abstract), Kraków 2.1: 154

47. Wang L (2019) High throughput circRNAs sequencing profile of follicle fluid exosomes of polycystic ovary syndrome patients. J Cell Physiol 234: 15537-15547

48. Rider MA, Hurwitz SN, Meckes DG Jr (2016) ExtraPEG: a polyethylene glycol-based method for enrichment of extracellular vesicles. Sci Rep 6: 23978
49. Field SL, Dasgupta T, Cummings M, Orsi NM (2014) Cytokines in ovarian folliculogenesis, oocyte maturation and luteinisation. Mol Reprod Dev 81: 284-314

50. Gross JC, Chaudhary V, Bartscherer K, Boutros M (2012) Active Wnt proteins are secreted on exosomes. Nat Cell Biol 14: 1036-45

51. Morales Dalanezi F, Mogollon Garcia HD, de Andrade Ferrazza R, Fagali Franchi F, Kubo Fontes P, de Souza Castilho AC, et al. (2019) Extracellular vesicles of follicular fluid from heat-stressed cows modify the gene expression of in vitro-matured oocytes. Anim Reprod Sci 205: 94-104

52. Hung WT, Hong X, Christenson LK, McGinnis LK (2015) Extracellular vesicles from bovine follicular fluid support cumulus expansion. Biol Reprod 93: 1-19

53. Hung WT, Navakanitworakul R, Khan T, Zhang P, Davis JS, McGinnis LK, et al. (2017) Stage-specific follicular extracellular vesicle uptake and regulation of bovine granulosa cell proliferation. Biol Reprod 97: 644-655

54. Saez F, Frenette G, Sullivan R (2003) Epididymosomes and prostasomes: their roles in posttesticular maturation of the sperm cells. J Androl 24: 149-154

55. Al-Dossary AA, Bathala P, Caplan JL, Martin-DeLeon PA (2015) Oviductosome-sperm membrane interaction in cargo delivery. J Biol Chem 290: 17710-17723

56. Martin-DeLeon PA (2016) Uterosomes: exosomal cargo during the estrus cycle and interaction with sperm. Front Biosci 8: 115-122

57. Campoy I, Lanau L, Altadill T, Sequeiros T, Cabrera S, Cubo-Abert M, et al. (2016) Exosome-like vesicles in uterine aspirates: a comparison of ultracentrifugation-based isolation protocols. J Trans Med 14: 180

58. Sang Q, Yao Z, Wang H, Feng R, Wang H, Zhao X, et al. (2013) Identification of microRNAs in human follicular fluid: characterization of microRNAs that govern steroidogenesis in vitro and are associated with polycystic ovary syndrome in vivo. J Clin Endocrinol Metab 98: 3068-3079

59. Taylor DD, Gercel-Taylor C (2008) MicroRNA signatures of tumor-derived exosomes as diagnostic biomarkers of ovarian cancer. Gynecol Oncol 110: 13-21

60. Zhou J, Gong G, Tan H, Dai F, Zhu X, Chen Y, et al. (2015) Urinary microRNA-30a-5p is a potential biomarkers for ovarian serous adenocarcinoma. Oncol Rep 33: 2915-2923

61. Carollo E, Paris B, Samuel P, Pantazi P, Bartelli TF, Dias-Neto E, et al. (2019) Detecting ovarian cancer using extracellular vesicles: progress and possibilities. Biochem Soc Trans 47: 295-304

\section{Exosomes as a new approach into cell-to-cell communication within the mammalian ovary}

\section{Katarzyna Popiołek ${ }^{1}$, Małgorzata Grzesiak ${ }^{2 \varpi}$}

${ }^{1}$ Department of Animal Physiology and Endocrinology, Faculty of Animal Science, University of Agriculture in Krakow, Krakow ${ }^{2}$ Department of Endocrinology, Institute of Zoology and Biomedical Research, Faculty of Biology, Jagiellonian University in Krakow, Krakow

$\llbracket$ Corresponding author: m.e.grzesiak@uj.edu.pl

Key words: exosomes, extracellular vessicles, follicular fluid, ovarian follicle

\section{ABSTRACT}

The ovarian follicle filled with follicular fluid creates an optimal environment for oocyte growth and maturation. Follicular fluid contains a wide range of biologically active molecules that regulate the functions of the oocyte and somatic cells in the ovarian follicle. Recently it has been confirmed that exosomes are present in the follicular fluid of human and animals. These nanosized, spherical structures surrounded by a lipid bilayer, carry an active biological charge as proteins, lipids, carbohydrates and genetic material. Due to the ability to passive migration in body fluids, exosomes move a long distances in the body and modulate the function of target cells. The importance of exosomes in the ovarian follicle is still not fully understood. To date their communication role and impact on physiological and pathological processes in the ovary are suggested. Research on follicular fluid derived exosomes provides an opportunity to better understand the processes in which they are involved within the follicle. In addition, the potential clinical application of exosomes, including treatment and diagnosis of female reproductive system diseases, leads scientists to further research. 